\title{
The Proper Scope of Government: Theory and an Application to Prisons
}

\section{Citation}

Hart, O., A. Shleifer, and R. W. Vishny. 1997. The Proper Scope of Government: Theory and an Application to Prisons. The Quarterly Journal of Economics 112, no. 4: 1127-1161. doi:10.1162/003355300555448.

\section{Published Version}

doi:10.1162/003355300555448

\section{Permanent link}

http://nrs.harvard.edu/urn-3:HUL.InstRepos:30727607

\section{Terms of Use}

This article was downloaded from Harvard University's DASH repository, and is made available under the terms and conditions applicable to Other Posted Material, as set forth at http:// nrs.harvard.edu/urn-3:HUL.InstRepos:dash.current.terms-of-use\#LAA

\section{Share Your Story}

The Harvard community has made this article openly available.

Please share how this access benefits you. Submit a story.

\section{Accessibility}


NBER WORKING PAPER SERIES

THE PROPER SCOPE OF GOVERNMENT:

THEORY AND AN APPLICATION

TO PRISONS

Oliver Hart

Andrei Shleifer

Robert W. Vishny

Working Paper 5744

\author{
NATIONAL BUREAU OF ECONOMIC RESEARCH \\ 1050 Massachusetts Avenue \\ Cambridge, MA 02138 \\ September 1996
}

We are grateful to Matthew Ellman for research assistance, and to Orley Ashenfelter, Gary Becker, Pranab Bhardan, John DiIulio, Jack Donahue, Henry Farber, Randall Filer, Ed Glaeser, Joseph Harrington, Martin Hellwig, Steve Kaplan, Lawrence Katz, John Kwoka, Bentley Macleod, John Matsusaka, Sam Peltzman, Rohan Pitchford, Raghu Rajan, Sherwin Rosen, Jean Tirole, Luis Ubeda, Mike Whinston, Chenggang Xu, Luigi Zingales, and many other colleagues for comments. We have also benefited from the reactions of seminar audiences at USC, Cal Tech, Harvard, McGill University, L.S.E., University of Chicago, Princeton University, University of Miami, Cornell University Law School, ECARE, George Washington University, Johns Hopkins University, University of Washington, Seattle, the Industry Economics Conference at Australian National University, Canberra, and the Harvard Political Economy group. Finally, we are grateful to the National Science Foundation for support of this work. This paper is part of NBER's research programs in Corporate Finance and Public Economics. Any opinions expressed are those of the authors and not those of the National Bureau of Economic Research.

(C) 1996 by Oliver Hart, Andrei Shleifer and Robert W. Vishny. All rights reserved. Short sections of text, not to exceed two paragraphs, may be quoted without explicit permission provided that full credit, including $\mathbb{C}$ notice, is given to the source. 


\title{
THE PROPER SCOPE OF GOVERNMENT: THEORY AND AN APPLICATION TO PRISONS
}

\begin{abstract}
When should a government provide a service inhouse and when should it contract out provision? We develop a model in which the provider can invest in improving the quality of service or reducing cost. If contracts are incomplete, the private provider has a stronger incentive to engage in both quality improvement and cost reduction than a government employee. However, the private contractor's incentive to engage in cost reduction is typically too strong because he ignores the adverse effect on non-contractible quality. The model is applied to understanding the costs and benefits of prison privatization.
\end{abstract}

Oliver Hart

Department of Economics

Littauer Center 220

Harvard University

Cambridge, MA 02138

and NBER

oliver_hart@harvard.edu

Robert W. Vishny

Graduate School of Business

The University of Chicago

1101 East 58th Street

Chicago, IL 60637

and NBER

vishy@gsb.uchicago.edu
Andrei Shleifer

Department of Economics

Littauer Center 315

Harvard University

Cambridge, MA 02138

and NBER

shleifer@fas.harvard.edu 
1. Introduction.

As a general rule, government employees provide most services paid for with tax revenues, such as the police, the milltary, operation of prisons, fire departnents and schools, collection of garbage, and so on. Yet in some cases, these services are privatized through government contracting out their provision to private suppliers. The cholce between Inhouse provision and contracting out has proved to be quite controversial. Advocates of government contracting point out that private suppliers deliver public services at a lower cost than public employees (Savas 1982, 1987, Logan 1990). The critics of government contracting, while quibbling with these figures, stress that the quality of public services that private contractors deliver is inferior to that delivered by public employees (AFSCME 1985, Shichor 1995). In this paper, we develop a theory of government ownership and contracting that may throw light on the cost and quality of service under alternative provision modes.

The perspective we adopt is that of incomplete contracts (Grossman and Hart 1986, Hart and Moore 1990, Hart 1995). Suppose that a public-spirited politician chooses between having a service delivered by a public agency and contracting it out. In the first case, the politician has to hire some public employees, and give then employment contracts specifying what they need to do. In the second case, the polfticlan has to sign a contract with a private supplier who in turn contracts with his employees. If the politician can sign a complete or comprehensive contract (with either employees or a contractor), he can achieve the same outcome in each case. From the traditional incentive viewpoint, motivating the contractors and the public employees presents the same problem to the politician even in the presence of moral hazard and adverse selection. To understand the costs and benefits of contracting out, we need to consider a 
situation where contracts are incomplete and where residual rights of control in uncontracted for circumstances are important in determining agents' incentives.

The assumption of contractual incompleteness is not hard to motivate once It is recognized that the quality of service the government wants often cannot be fully specified. Indeed, critics of privatization frequently appeal to the argument that private contractors would cut quality in the process of cutting costs because contracts do not adequately guard against this possibility. Critics of private schools fear that such schools, even if paid for by the government (e.g., through vouchers), would find ways to reject expensive-toeducate children, who have learning or behavioral problems, without violating the letter of their contracts. Critics also worry that private schools would replace expensive teachers with cheaper teachers' aides, thereby jeopardizing the quality of education. In the discussion of public vs private health care, the pervasive concern is that private hospitals would find ways to save money by shirking on the quality of care or refecting the extremely sick and expensive-to-treat patients. In the case of prisons, concern that private providers hire unqualified guards to save costs, thereby undermining safety and security of prisoners, is a key objection to privatization. Fear that contracts cannot assure adequate quality is at the heart of many debates over government contracting.

In some cases, the problems of contractual incompleteness make the case for In-house provision by the government straightforward. For example, a government would not contract out the conduct of its foreign policy because unforseen contingencies are a key part of foreign policy, and a private contractor would have enormous power to maximize its own wealth (by, for Instance, refusing to send troops somewhere) without violating the letter of the contract. If the 
government wants such a contractor to do something different, it would have to pay possibly huge amounts to renegotiate the contract. Put differently, getting the right level of quality out of a private contractor might be very expensive. On the other hand, for services provided on a routine basis, with relatively few surprises, contracts can be made relatively complete. For example, contractual incompleteness does not play an lmportant role in garbage collection or towing of automobiles, and great sacrifices of quality are not likely to come from costcutting by private contractors. On the other hand, the efficlency gains from cost-cutting may be substantial. For these services, therefore, the normative case for privatization is compeli1ng. It is also important to recognize that, for many activities, such as just about any industry, private contractors deliver both lower costs and higher quality. As a general rule, government ownership is a mistake on both margins. Our model tries to explain both why private contracting is generally cheaper, and why in some circumstances it may deliver a higher, while in others a lower, quality level than inhouse provision by the government.

Many discussions of privatization lump together the issue of public or private ownership with the issue of competition. That is, those who advocate privatization often do so on the grounds that private ownership allows the benefits of competition to be reaped. We belleve that the identiflcation of privatization with competition is misleading. In principle, it is possible to have several government-owned firms competing to supply the public, or several managenent teans competing for the right to run a government enterprise (e.g., a prison). It is also possible to have a private firm with no effective competitors (a monopoly). Our analysis is based on the Idea that the fundamental difference between private and public ownership concerns the allocation of 
residual control rights, rather than the degree of competition per se. Competition may strengthen the case for privatization--in fact we show that it does under some conditions--but only because the allocation of residual control rights is different under privatization. In this paper we deal with the role of competition only briefly, although we belleve that this is a very important topic for future research.

In the next section of the paper, we present a model of government contracting which focuses on these quality issues. The basic Idea of the model is that the provider of the service -. whether a government employee or a private contractor -- can invest his time to improve the quality of the service or to reduce its cost. The cost reduction, however, has an adverse effect on quality. Neither innovation is contractible ex ante. However, both types of innovation, to be implemented, require the approval of the owner of the asset, such as a prison, a hospital, or a school. If the provider is a government employee, he needs the government's approval to implement elther Improvement, since the government retains residual control rights over the asset. As a result, the employee receives only a fraction of the returns to elther the quality Improvement or the cost reduction. Moreover, there may be a limit to how well a government employee can be compensated for either improvement because the employee is replaceable.

In contrast, if the provider is a private contractor, he has the residual control rights over the asset, and hence does not need to get the government approval for a cost reduction. At the same time, if he wants to improve quality and get a higher price, he needs to negotiate with the government since the government is the buyer of the service. However, he is no longer replaceable. As a consequence, the private contractor generally has a stronger incentive to 
engage in either quality improvement or cost reduction than the government employee. But, the private contractor's incentive to engage in cost reduction is typically too strong since he Ignores the adverse impact on quality.

We analyze this model in Section 3 and establish several propositions concerning the relative effictency of Inhouse provision and government contracting. In general, the bigger the adverse consequences of (noncontractible) cost cutting on (non-contractible) quality, the stronger is the case for Inhouse provision. The efficlency of Inhouse proviston also turns on the strength of the incentives of government employees, and on the importance to the government of generating quality innovations. We show in Section 3 that the conclusions emerging from the model are generally extremely intuitive, including the result that private provision is generally cheaper, but may generate either higher or lower quality. Section 3 also brlefly addresses a key omission from the model, namely the possibility of ex post competition between contractors, which typically strengthens the case for privatization.

The basic model in Section 2 deals with a benevolent government. Many of the concerns about government contracting, however, deal with the realtty of a less than perfect government, in which politicians are corrupt or interested in favoring their political supporters to attract votes. In section 4, we argue that public corruption creates a bias toward excessive privatization, whereas an interest in votes of public employees creates the reverse bias. With selfish politicians, the efficiency of alternative arrangements turns on which failure of the public sector is the most important.

In section 5, we apply the framework of sections $2-4$ to discuss privatization of prisons. Should the government contract out the operations of prisons to private firms, who then have power over incarceration and treatment 
of convicts? Private prisons have been growing rapidly in the United States, although they still hold only about 3 percent of prisoners. Critics voice a strong concern about the quality of private incarceration, including the quality of prisoner life, the incidence of prison violence by inmates and use of force by guards, escapes, and to a lesser extent rehabilitation.

The analysis of prison privatization fits nicely into our framework. Although many aspects of quality can in fact be contracted for, and prison contracts tend to be rather elaborate documents, significant contractual Incompleteness remains. For example, it is hard to write a contract complecely specifying the conditions for the use of force by guards, since the circumstances under which force is justified are subject to interpretation. Private contractors, then, wight use force excessively to restrain prisoners if this reduces costs. Even more important, it is difficult to specify in the contract the quality of employees, such as guards and managers, that a private contractor hires. Hiring cheaper employees (within the limits set by the contract) can save a private contractor money but is likely to reduce the quality of prisoner treatment. Last but not least, some recent evidence indicates that the government's abllity to write and enforce the best possible contract should not be taken for granted. Overall, the theoretical results of sections 3 and 4 , when combined with the avallable evidence, suggest some skepticism about the wisdom of prison privatization.

Our results may help in thinking about other government services as well. In particular, the parameters of the model, namely the adverse quality effects of cost reduction, the importance of quality innovation, and the incentives of government employees, as well as possibilities of competition which we do not formally model, may shed light on the wisdom of privatization of such activities 
as defense procurement, garbage collection, police and armed forces, education, and health. In section 6 , we discuss in more general terms the applicability of our framework to the study of government contracting.

Ours is certainly not the first normative analysis of government contracting ${ }^{2}$. Some of the issues addressed in our paper are raised in the nowclassic book by Wilson (1989). Economists working in this area have generally focused on traditional adverse selection and moral hazard problems ralsed by contracting (Laffont and Tirole 1993, Tirole 1994), as well as on competitive and ant1-monopoly problems following privatization (Vickers and Yarrow 1988). Some recent studies have examined contractual incompleteness (Schmidt 1996, Shapiro and Willig 1990, Laffont and Tirole 1993). Unlike our work, they have emphasized Informational losses from contracting or the costs of having multiple bosses. Theoretically, our paper is new primarily in deemphasizing the role of incomplete Information in contracting, and emphasizing the critical importance of quality 1ssues. In this regard, our paper is related to the work of Holmstrom and Milgron (1991, 1994) who, In a comprehensive contracting framework, note that providing an agent with strong incentives to pursue one objective, such as profits, can lead to his shirking on other objectives, such as quality. Our framework is different from theirs, although at a very general level the issues we are interested in are similar. In addition, the existing literature is primarily theoretical, and does not go into too much detall about the problems of specific sectors, such as prisons ${ }^{3}$.

\footnotetext{
${ }^{2}$ There is also a considerable literature on positive aspects of contracting; see e.g. Shlelfer and Vishny (1994) and Savas (1982, 1987).

3 There are some exceptions. For example, Vickers and Yarrow (1988) discuss the possible decline in quality at British Telecom following privatization and price cap regulation. Domberger, Hall and Li (1995) examine the consequences for price and quality of contracting out cleaning services.
} 


\section{The Model}

\section{Basic Assumptions}

In this section we present a simple model of the choice between the public and private provision of a good, such as prison, hospital, or school services.

Suppose that soclety, represented by the government, wants a certain good or service to be provided. We assume that consumers cannot buy this good directly in the narketplace, e.g., because it is a public good.4 One possibility is to contract out the provision of this good, e.g., the government can write a contract with a private company to run a prison for five years. A second possibility is to provide the good "In-house," e.g., the government can arrange for public employees to run the prison. The model is based on the idea that the crucial distinction between these arrangements concerns who has residual rights of control over the nonhuman assets used to provide the service--we call these assets the "facility $F^{n}$ (e.g., the prison). If the good is publicly provided, then the government (represented by a bureaucrat), as owner, has residual control rights over the facility. If the good is privately provided, then the private provider, as owner, has residual control rights over the facility. Residual control rights matter because they determine who has the authority to approve changes in procedure or innovations in uncontracted for contingencies. 5

This assumption makes good sense in the case of prisons but is more controversial in the case of schools or hospitals.

${ }^{5}$ See Grossman and Hart (1986). What may be more important is not who owns the physical prison, but who has the right to use it (perhaps for a restricted period of time). For example, the government may own the prison, but sell the right to operate it to a private company for $n$ years (a franchising arrangement). In this case, the private company has residual control rights during the $n$ year period. In this paper, we do not distinguish between physical ownership and possession of the right to use the prison. 
We suppose that the facility--public or private--is run by a single nanager/worker, M. There is also a single bureaucrat or politiclan, represented by $G$. We start by considering the case where the bureaucrat perfectly represents the interests of soclety, 1.e., there is no agency problem between the bureaucrat and society. 6 Later we consider self-interested bureaucrats and politicians.

We assume that $G$ and $M$ are able to write a long-term contract specifying some aspects of the good or service to be provided and the price. In fact, we suppose that a long-term contract is required in the case where $F$ is private in order to support relationship-specific investments. ${ }^{7}$ We call the good thus described in the contract the "basic" good and denote its price by $P_{0} . P_{0}$ has different interpretations according to whether the facility $F$ is private or public. If $F$ is private, 1.e., $M$ owns $F$, then $P_{0}$ is the price that $M$ as an Independent contractor receives for providing the basic good. If $F$ is public, 1.e., G owns $F$, then $P_{0}$ is the wage that $M$ receives as an employee. In the latter case provision of the basic good can be regarded as part of M's Job description, 1.e., M does not get paid unless he provides the good.

Although $G$ and $M$ can specify some aspects of the good or service in advance, we suppose that there are others that they cannot specify. We have in nind that various contingencles can arise which call for some modification of the

\footnotetext{
'To be more precise, we assume that G's utility function is given by the welfare of the rest of society, excluding $M$. A justification for this is that the political process aligns G's and soclety's interests (since $M$ has negligible voting power his interests receive negligible weight). As will become clear, if G's utility encompassed M's interests as well, the first-best could be achieved.

${ }^{7}$ We do not model these relationship-specific investments explicitly. However, they might correspond to physical investments, e.g., bullding the prison. We have in mind that the owner must incur these investment costs since if a non-owner incurs the cost he can be held up by the owner. For the idea that a long-term contract is required to support relationship-specific investments, see Klein et al. (1978) and Willtamson (1985).
} 
basic good. For instance, $M$ can suggest a way to modify the prison to increase security. Alternatively, M may find a way to reduce costs by hiring cheaper (or fewer) guards. Our assumption is that there are so many possible contingencles ex ante that it is impossible to anticipate them all and contract on how to deal with them in advance. Instead the parties revise the contract ex post once it is clear what the relevant contingencles are. We refer to the basic good modifled to allow for relevant contingencles as the "modifled good."

The modifled good yields a benefit B to society and costs the manager $C$ to produce. C is a cost borne directly by $M$. For example, B might be the social benefit from having a prison with few fights between inmates and well fed and healthy prisoners. Although B cannot be measured or verified (it does not show up in any accounts), we suppose that it can be represented by a dollar amount. Similarly, C can be represented in dollars.

The manager can manipulate $B$ and $C$ through prior effort choices. We assume that $M$ can devote effort to two types of "innovation" relative to the basic good: a cost innovation and a quality innovation. We suppose that a cost innovation leads to a reduction in costs $C$ but is typically accompanied by a reduction in quality (1.e., B). Similarly, a quality innovation leads to an increase in quality, but is typically accompanied by an increase in costs. Specifically, we write:

$$
\begin{aligned}
& B-B_{0}-b(e)+\beta(1), \\
& c-C_{0}-c(e),
\end{aligned}
$$

B For a further discussion, see Hart (1995). 
where $e, 1$ denote effort devoted to the cost Innovation and quality innovation, respectively; $c(e) \geq 0$ is the reduction in cost corresponding to the cost Innovation; $b(e) 20$ is the reduction in quality corresponding to the cost Innovation; and $\beta(1) \geq 0$ is the quality increase net of costs from the quality innovation'. The function b plays a key role in this model: it measures how much (non-contractible) quality might fall because of a (non-contractible) cost cut, and hence serves as the variable that critics of privatization focus on.

We make standard assumptions about the convexity, concavity, and monotonicity of $b, c$ and $\beta: b(0)-0, b^{\prime} \geq 0, b^{\prime \prime} \geq 0 ; c(0)-0, c^{\prime}(0)-\infty, c^{\prime}$ $>0, c^{\prime}<0, c^{\prime}(\infty)-0 ; \beta(0)=0, \beta^{\prime}(0)-\infty, \beta^{\prime}>0, \beta^{\prime}<0, \beta^{\prime}(\infty)-0 ; c^{\prime}-$ $b^{\prime} 20$. Note that the assumptions $c^{\prime}-b^{\prime} \geq 0, \beta^{\prime}>0$ say that the quality reduction from a cost Innovation does not offset the cost reduction; and the cost increase from a quality innovation does not offset the quality increase. The former, In particular, is an important substantive assumption, since one can imagine in principle that cost cutting by a contractor (e.g., falling to train prison guards) produces social damage in excess of cost savings. Our assumption rules out these cases, although they can be easily analyzed.

The manager's ex ante effort cost must be added to $C$ to get $M$ 's overall costs. We write total effort costs as $e+1$, and assume a zero interest rate (no discounting). Hence M's overall costs are

$$
c+e+1-C_{0}-c(e)+e+1.10
$$

We need to keep track of the separate cost and quality components of the cost Innovation ( $c$ and $b$ ), but not of the quality innovation.

10 In an earlier version of this paper, we assumed a more complicated cost-of-effort function in which $e$ and $i$ were substitutes (along the lines of the multi-tasking work of Holmstrom and Milgrom (1991)). The current model generates simpler and easier-to-interpret results. 
One important assumption we make is that both the cost and quality Innovations can be introduced without triggering a breach of the contract for the basic good. That is, although each innovation leads to a change in quality (In the case of the cost innovation, a reduction in quality), the initial contract Is sufficiently vague or "incomplete" that neither innovation violates it.

We also assune that $1, e, b$, and $c$ are observable to both $G$ and $M$, but are not veriflable (to outsiders) and hence cannot be part of an enforceable contract. Similarly, G's benefits and M's costs are observable, but not veriflable or transferable, which means that revenue and cost-sharing arrangements are infeasible. ${ }^{11}$

We suppose that $G$ and $M$ are at least partlally locked into each other once their relationship is underway. Specifically, there is no facility other than F avallable that can supply society and there is no other potential customer for the service (e.g., a prison) apart from G. However, M's labor services may be partially substitutable (see below). Finally, we assume that $M$ and $G$ are risk neutral and that there are no wealth constraints. A time-line is presented in Figure 1 .

\section{Default Payoffs}

As noted, the parties want to renegotlate the contract at date 1 once they learn the nature of potential quality improvements and cost reductions. We assume that $G$ and $M$ divide the gains from renegotiation according to Nash bargaining, 1.e., they split the surplus $50: 50$. This means that the parties' default payoffs--that is, what occurs in the absence of renegotiation-- influence

\footnotetext{
11 For a more extensive discussion of veriflabllity, noncontractibility, and revenue and cost-sharing arrangements, see Hart (1995).
} 
final payoffs.

We take the point of view that any cost or quality innovation requires the agreement of the owner of the facility F, since implementing these innovations Involves a change in the way $F$ is used. Only the owner (the possessor of the residual control rights) has the right to approve such a change. Thus, in the case of a public facllity, G needs to agree to any cost or quality innovation, whereas, if the facility is private, M can implement these innovations without G's agreement. However, even if the facilty is private, it is not in M's interest to Introduce a quality innovation without the approval of $G$ since no payment will be forthcoming for an uncontracted-for quality improvement unless G agrees to make $1 t, 1 . e .$, unless a new contract is written.

It remains to discuss the extent to which the fruits of M's efforts $e$ and 1 are embodied in M's human capital. Suppose that if $M$ has an Idea about how to reduce costs or Increase quality then a fraction of the benefits of this idea requires M's participation but the remainder can be realized without $M$ because some aspects of M's Ideas become public knowledge (at least within the organization). In particular, assume that, in the case where $F$ is public, $G$ can realize a fraction $0 \leq(1-\lambda) \leq 1$ of the net social gains $-b(e)+c(e)+\beta(1)$ from Innovation without $M$ by hiring a different manager and paying him at cost. If $F$ is private, $G$ can obtain none of these benefits since $M$ has the residual control rights and can prevent any Innovations. The parameter $\lambda$ is very Important, since it effectively measures the weakness of the incentives of government employees. In the case $\lambda-1$, the public employee (warden) is Irreplaceable, and hence can command the same share of the total rents in the negotiation with $G$ as a private manager.

We can sum up the above discussion as follows: 
(A) If $F$ is privately owned, then, in the absence of renegotfation, the cost innovation is implemented (since It Is In M's interest to implement it and $M$ has the residual control rights) but the quality innovation is not (since no payment from $G$ will be forthcoming). That 1s, G's default payoff is $B_{0}-P_{0}-b(e)$ anndM's default payoff is $P_{0}-C_{0}+c(e)-e-1$.

(B) If $F$ is publicly owned, then, in the absence of renegotiation, both cost and quality innovations are 1mplemented. However, $G$ must replace $M$ and hence gets only a share $(1-\lambda)$ of the gains from these innovations. That is, G's default payoff is $B_{0}-P_{0}+$ $(1-\lambda)[c(e)-b(e)+\beta(1)]$ and $M^{\prime} s$ default payoff is $P_{0}-C_{0}-e-1$.

\section{The First-Best}

It is useful to consider as a benchmark the first-best situation where e and 1 are contractible (or equivalently, where long-term contracts describing the modifled good can be written). In this case $G$ and $M$ would choose $e$ and $i$ to maximize the total net surplus from their trading relationship, and divide the surplus between them using lump-sum transfers. That is, in the first-best, $G$ and M solve:

$$
\operatorname{Max}_{e, i}(c(e)-b(e)+\beta(i)-e-i) .
$$


Given our assumptions, (2.1) has a unique solution (e*, 1*), characterized by first order conditions:

$$
-b^{\prime}\left(e^{\star}\right)+c^{\prime}\left(e^{*}\right)-1 \text {, }
$$

$$
p^{\prime}(1 *)-1 \text {. }
$$

At the social optimum, the marginal soclal benefit of spending extra effort to reduce costs, measured to take account of marginal quality deterioration, must equal the marginal cost of that extra effort, which equals 1 . Similarly, the marginal social benefit of spending extra effort to Improve quality must equal the marginal cost of that extra effort, which again equals 1 .

\section{Equilibrium under Private Ownership}

Suppose M owns F. Then in light of (A), the renegotiation takes place over the quality innovation. The gains from renegotiation are $\beta(1)$, which are split 50 : 50 . (There is symmetric Information about 1.) Thus, the parties' payoffs are

$$
\begin{aligned}
& U_{G}-B_{0}-P_{0}+1 / 2 \beta(1)-b(e), \\
& U_{M}=P_{0}-C_{0}+1 / 2 \beta(1)+c(e)-e-1 .
\end{aligned}
$$

Note that because $M$ can reduce costs without seeking G's approval, G bears the full brunt of quality deterioration resulting from cost reduction.

Since the parties are assumed to have rational expectations, $M$ chooses $e$ and 1 to maximize $U_{M}$, that is, to solve 


$$
\operatorname{Max}_{e, 1}(1 / 2 \beta(1)+c(e)-e-1) .
$$

Denote the (unique) solution by $\left(e_{m}, 1_{m}\right)$ (where $M$ stands for ownership by $M$ ). The first order conditions for $(2.6)$ are

$$
c^{\prime}\left(e_{n}\right)-1
$$

$$
1 / 2 \beta^{\prime}\left(1_{N}\right)-1
$$

There are two deviations from first-best here. First, $M$ ignores the deterioration of quality resulting from cost reduction, and hence exaggerates the social benefit of cost reduction. Second, because M must get G's approval to implement a quality Improvement, on the margin he gets only half the benefits of that improvement, which stunts his incentive to improve quality.

The total surplus, $S_{N}$, under M's ownership is then given by

(2.9) $S_{M}-U_{G}+U_{M}=B_{0}-C_{0}-b\left(e_{M}\right)+c\left(e_{M}\right)+B\left(I_{M}\right)-e_{M}-I_{M}$.

The price $P_{0}$ is chosen to allocate this surplus between the parties according to their relative bargaining positions at date 0 . The formula for $S_{m}$ reflects the fact that the parties bargain efficiently ex post, but there is a distortion in relationship-specific investments $e$ and 1 .

\section{Equilibrtum under Public Ownership}

Suppose $G$ owns F. Then In light of (B) the renegotiation takes place over the fraction $\lambda$ of both the cost and quality innovations that $G$ cannot 
appropriate: $\lambda[-b(e)+c(e)+\beta(1)]$. The galns are split $50: 50$, and so the parties' payoffs are

$$
\begin{aligned}
& U_{G}-B_{0}-P_{0}+(1-\lambda / 2)[-b(e)+c(e)+\beta(1)] \\
& U_{M}-P_{0}-C_{0}+\lambda / 2[-b(e)+c(e)+\beta(1)]-e-1 .
\end{aligned}
$$

Note that, in the case $\lambda-1$, when the manager is completely irreplaceable, the parties split the gains from Innovation 50:50. M chooses a and 1 to solve

$$
\operatorname{Max}_{e, 1}(\lambda / 2[-b(e)+c(e)+\beta(1)]-e-1\} .
$$

Denote the (unique) solution by $\left(e_{G}, I_{G}\right)$ (where $G$ stands for ownership by $G$ ). The first order conditions for (2.12) are

$$
\lambda / 2\left(-b^{\prime}\left(e_{G}\right)+c^{\prime}\left(e_{G}\right)\right)=1,
$$

In contrast to the private ownership case, because the publicly-employed M needs to negotiate the cost reduction with $G$, he takes account of quality reductions that may result from cost-cutting Innovations. However, there are new distortions in the case of public ownership. First, for both quality and cost innovation, the public manager needs the approval of $G$ and hence surrenders half the gains from trade. Second, if $\lambda<1$, the public manager can be replaced, and hence has even weaker incentives to innovate. Both of these factors stunt a 
public manager's Incentives.

The total surplus, $S_{G}$, under $G$ ownership is then given by

$$
S_{G}-U_{G}+U_{M}-B_{0}-C_{0}-b\left(e_{G}\right)+c\left(e_{G}\right)+B\left(I_{G}\right)-e_{G}-I_{G} .
$$

Again the price $P_{0}$ is chosen to allocate the surplus at time 0 according to relative bargaining power.

The Choice of Ownership structure

The optimal ownership structure is the one that produces the largest total surplus (the division of surplus can always be adjusted through $P_{0}$ ). That is,

G ownership is superior to $M$ ownership

$$
\begin{aligned}
& -S_{G}>S_{M} \\
& --b\left(e_{G}\right)+c\left(e_{G}\right)+\beta\left(1_{G}\right)-e_{G}-I_{G}>-b\left(e_{M}\right)+c\left(e_{M}\right)+\beta\left(1_{M}\right)-e_{M}-1_{M}
\end{aligned}
$$

Renegotiation under symmetric information ensures that all ownership structures yield an ex post efficient outcome. The only difference between the ownership structures concerns the choice of the ex ante investments $e$ and 1 .

3. Analysis of the Optimal Ownership Structure.

A comparison of (2.1) and (2.6) shows that private ownership leads to two distortions relative to the first-best. First, M ignores the fact that e reduces noncontractible quality $b(e)$; In other words, that he damages $G$ through his effort to reduce costs. Second, M places 50 weight on the gains from quality innovation $B(1)$ as opposed to 1008 weight. It follows immediately from the 
first-order conditions (2.2), (2.3), (2.7), (2.8) and concavity that $e$ is Inefficiently high and 1 is inefficiently low under private ownership.

Proposition 1. $\quad e_{M}>e^{*}, 1_{N}<1^{*}$.

The private ownership equflibriun is fllustrated in Figure 2.

Consider next public ownership. A comparison of (2.1) and (2.12) shows that under public ownership, $M$ does worry about the damage $b(e)$. The reason is that $M$ cannot implement the cost reduction without G's permission and so they bargain about the net surplus $-b(e)+c(e)$ from the cost-reducing innovation. However, M places welght $2 / 2$ on the gains from cost Innovation $-b(e)+c(e)$ and on the gains from quality innovation $\beta(1)$, as opposed to 100 weight in the first best. It follows from the first-order conditions (2.13)-(2.14) that e and 1 are both Inefficiently low under public ownership. Moreover 1 is lower under public than under private ownership unless $\lambda-1,1 . e .$, unless $M$ is irreplaceable.

Propostition 2. $e_{G}<e^{*}, 1_{G} \leq i_{M}<1^{*}$ (with $i_{G}<i_{M}$ unless $\lambda-1$ ).

The public ownership equilibrium is also illustrated in Figure 2.

The trade-off between public and private ownership is now fairly clear. Private ownership leads to an excessively strong Incentive to engage in cost reduction $\left(e_{M}>e^{*}\right)$ and to moderate--although still too weak--incentives to engage in quality improvement $\left(I_{N}<1^{*}\right)$. Public ownership removes the excessive tendency to engage in cost reduction but replaces this with a weak incentive to engage in both cost reduction and quality improvement. Which arrangement is superior therefore depends on which distortion is less damaging. 
The next two propositions provide conditions under which private ownership and public ownership can be ranked.

Proposition 3. (1) Suppose the function $b(e)$ is replaced by $\theta b(e)$, where $\theta>0$. Then for $\theta$ sufficiently small private ownership is superior to public ownership.

(2) Suppose the function $b(\theta)$ is replaced by $\theta b(e)$ and the function $c(e)$ is replaced by $\phi c(e)$, where $\theta, \phi>$. Then, for $\theta, \phi$ suffictently small and $\lambda<1$, private ownership is superior to public ownership.

Part (1) of Proposition 3 follows from the fact that, as $\theta \rightarrow 0$, the damage to quality from cost reduction disappears. Under these conditions, private ownership leads to the efficient cholce of $e$ (since $c^{\prime}(e)--b^{\prime}(e)+c^{\prime}(e)$ ). Since the level of $i$ is always closer to the first-best under private ownership than under public ownership, private ownership dominates public ownership. Part (2) follows from the fact that, as $\theta, \phi \rightarrow 0, e^{*}, e_{M}$ and $e_{G}$ all converge to zero. Thus, only the choice of 1 matters; private ownership is better than public ownership because it ylelds a level of 1 closer to $1 *$.

Proposition 3 has a very natural interpretation. There are basically two cases when private ownership is unambiguously superior. The first case is when the deterioration of quality from cost reduction is small. In this case, the stronger Incentives that a private contractor has to reduce costs and improve quality are both desirable. The second case is when the opportunities for cost reduction (and hence the damage to quality as well) are small and the government employees have relatively weak incentives ( $\lambda$ is small). In this case, the private contractor would not do much of the potentially damaging cost reduction, and his stronger incentive to make quality innovations gives him the 
edge over inhouse provision. Both of these are extremely intuitive cases.

The cases where inhouse provision is superior are given by the following result:

Proposition 4. (1) Suppose $-b(e)+c(e)-\operatorname{od}(e)$, where $0>0$. Then for 0 sufficiently small and $\lambda$ sufficiently close to 1 , public ownership is superior to private ownership.

(2) Suppose $-b(e)+c(e)-\sigma d(e)$, where $0>0$. Suppose also that the function $\beta(i)$ is replaced by $\tau \beta(i)$, where $\tau>0$. Then for $\sigma, \tau$ sufficiently small public ownership is superior to private ownership.

Part (1) follows from the fact that as 0 - 0 the social gains from cost reduction converge to zero: the quality damage fully offsets the cost savings. Thus the weak incentives for cost reduction under public ownership are socially efficient. In contrast, the incentives for cost reduction under private ownership are inefficient, since the private owner Ignores the substantial damage $b(e)$. If $\lambda$ is close to 1 , the incentives for quality innovation under public ownership are similar to those under private ownership, and so public ownership dominates private ownership.

Part (2) replaces the condition 2 close to 1 with the condition that $\tau$ is small. In this case $1^{*}, I_{M}$ and $I_{G}$ are all approximately zero and so only the cholce of e matters. For o small public ownership is superior to private ownership because it delivers a socially more efficient level of $e$.

Proposition 4 as well has a very natural interpretation. Public ownership is most likely to be better when the adverse effect of cost reduction on quality is large. But that is not enough. For public ownership to be definitely 
superfor 1t must also be the case that either quality improvement is unimportant or that government employees do not have weaker incentives in quality improvement ( $\lambda$ is large). If one of the latter conditions holds, then private contractors are not significantly superior at improving quality, and hence public ownership $1 s$ preferred. 12

Finally, we consider the cost/quality comparison between private and public ownership:

Proposition 5: Costs are always lower under private ownership. Quality may be higher or lower under private ownership.

We know that $e$ is higher under private ownership than under public ownership $\left(e_{M}>e^{\star}>e_{G}\right)$ and hence costs are always lower under private ownership. Quality $-b(e)+B(1)$ may be higher or lower since, although $e$ is higher, so is 1 . One case where quality is higher under private ownership is when $b^{\prime}(e)$ is small (more precisely, we replace $b(e)$ by $\theta b(e)$ and let $\theta-0$ );

\footnotetext{
${ }^{12}$ We have analyzed private ownership under the assumption that the private owner actually manages the firm. This is not a bad assumption for the case we are most interested in--prisons. In future work, however, it would be useful to extend the analysis to situations where there is a separation between ownership and control. Some of the most important trade-offs that we have identified are still likely to be relevant. Note in particular that it will still be the case that the owners and managers of a private firm have an excessive tendency to reduce costs, since they can collectlvely divide the gains from cost reduction among themselves, ignoring the adverse quality impact on society. The implications for quality innovation are more complicated. To the extent that the manager of a private firm is less replaceable than the manager of a public firm (because the private company's shareholders are dispersed, say), the private company manager's incentives to Innovate will be greater than the public manager's. However, to the extent that the manager of a private firm must share the fruits of his innovation with both his owner(s) and the government, as opposed to just the government, the private manager's incentives to innovate will be smaller (on the latter effect, see Laffont and Tirole (1993) and Hart and Moore (1990)).
} 
then quality is determined by differences in 1 and not differences in e. On the other hand, if $\beta^{\prime}(1)$ is small, quality is higher under public ownership; in this case quality is deternined by differences in e rather than differences in 1 .

Proposition 5 explains what we belleve to be the basic stylized facts, namely that private contracting typically yields greater cost efficiency, but there is ambigulty about quality. Note that we could not get ambigulty if we had a almpler model, in which there is no investment in quality improvement. In that model, there would be a straight tradeoff between quality and cost, with public provision delivering more quality at a higher cost. That model (1.e., one without $\beta$ ) would resemble the comprehensive contracting treatment of Laffont and Tirole (1993, chapter 4), who argue that higher powered incentives (which might be associated with private ownership) lead to both lower costs and quality. Our model, in contrast, explains why in some - - arguably most - - cases private provision leads to both lower costs and higher quality.

\section{Competition}

Perhaps the single most 1mportant issue that our model does not deal with Is ex post competition between the suppliers of the good. Competition may not always be a relevant option. For example, letting prisoners choose their prison and having prisons compete for inmates is probably a bad idea. However, in other cases, competition might be very beneficial.

To take the simplest case, suppose that the consumers buy the good, or service, directly from a contractor, without any government intervention, even In financing. Suppose also that the consumers can assess the quality on their own (a good assumption with most goods, a plausible assumption for education, and probably the wrong assumption for health). Suppose finally that the suppliers 
are perfectly competitive at every quality level. In this case, a private contractor would face exactly socially optimal incentives, since, on the margin, he gets a lower price for any quality shortfall resulting from a cost reduction, and a higher price for any quality improvement through Innovation (that is, he recelves $-b(e)+c(e)+\beta(1))$. Private supply in this case delivers the first best. On the other hand, a public manager needs to negotiate any Innovation with the governenent, and might be replaceable, so his Incentives to innovate are stunted. In this extreme case - - where there is no need for the government at all - the private sector delivers the first-best and public provision is Inefficlent. Competition makes the cholce between the mode of supply trivial. of course, in most interesting cases, the situation is more complicated, and some government role is needed, at least in financing. For example, in education, even if the supppliers are private and competitive, most arrangements would allow for the government to pay for the service of at least some consumers (e.g., through vouchers). The Idea is that the government needs to participate in the financing of these services to reduce inequality of consumption across consumers. In these arrangements, as long as consumers can assess quality, it is still likely that, to the extent that there is consumer choice and competition between suppliers, private suppliers would pay for deterloration in quality resulting from cost reduction because the consumers can go elsewhere. In this case, competition again generally strengthens the case for contracting out.

The objections to private, competitive supply typlcally focus on more subtle distributional issues. One argument is that private suppliers paid a fixed sum by the government would refuse to supply consumers who are expensive to service (e.g., they would not educate difficult children). Another argument is that, under private arrangements, sorting that is inefficient from the social 
viewpoint would result (e.g., good schools would only accept smart children, leaving other children to bad schools). As we argue in section 6, it is sonetines - though not always -- possible to come up with private, competitive contractual arrangements that can successfully address these distributive concerns. However, we leave a full discussion of competition and regulation to a separate paper.

4. Alternative views of government.

In this section we relax the assumption that the bureaucrat/politician acts on behalf of soclety, that is, we allow for the possibility that the politician is self-interested. This self-interest can express itself in a number of ways. First, the politician may be corrupt, in the sense of being willing to use his control rights to extract money (or campaign contributions) for himself from the contractor. Second, the pollticlan may use his control rights to pursue political objectives other than the public interest, such as catering to interest groups that might support him in the election. These alternative characterizations of political behavior have significant implications for the optimality of alternative ownership structures.

Corruption

A corrupt politician overseeing the delivery of a government service can benefit himself in many ways. If the service is contracted out, the politician can try to award the contract to a supplier who does not make the lowest bid or who delivers a lower quality, in exchange for a bribe. The politician can also write a contract that is disadvantageous, e.g., one that intentionally ignores important quality issues or pays excessive prices. When such a contract needs 
to be renegotiated, the politician can renegotiate it on terms advantageous to the contractor. Last but not least, once the contract is awarded, the politician may accept the violation of its terms, and fall to enforce important provisions. In short, a corrupt government official can use a varlety of powers at his disposal to reduce the quality and raise the cost of services to the government, and collect bribes in exchange ${ }^{13}$.

We do not analyze all these models of corruption in this paper. Instead, we describe one simple -- but possibly important -- case, in which corruption leads to an excessive tendency to privatize. That is, a corrupt official privatizes when in-house provision is socially preferred.

Suppose the privatization decision is made by a higher level politician at some date before date 0 (see Figure 1). That is, assume that the time line is as in Figure 1 except that the ownership decision is made at date $-\frac{1}{2}$. Suppose also that the politician is not involved in $F^{\prime} s$ operations after the privatization decision, that is, contracting decisions pass to a bureaucrat who is assumed to be honest. In contrast, the politician is corrupt and takes monetary bribes.

Under these conditions the politician has a simple choice. He can privatize F (a prison) --In which case he arranges to sell it to a private company owned by $M$ (the future owner-manager of $F$ ). Suppose that the politician can set the price artificlally low and extract a bribe from $M, 1 . e$. the politician can avoid selling $F$ through competitive bidding. Alternatively, the

${ }^{13} \mathrm{~A}$ very similar set of issues arises when the politician is lazy or unmotivated. Such a politician, like his corrupt counterpart, may write bad contracts that fall to protect the public, award contracts to inefficient suppliers, pay excessive prices, fail to supervise contractors, etc. Because privatization locks the government into these bad arrangements, laziness of politiclans, like corruption, tends to point against privatization. 
politiclan can keep $F$ public and appoint $M$ as the future manager (the warden). In this situation we suppose that the politician can extract a bribe from $M$ in return for M's future benefits as manager.

Under reasonable assumptions the politiclan can extract a nuch higher bribe if he privatizes $F$ than if he does not. If the politician privatizes $F$ then, at date 0 , M is in a bilateral bargaining position with the bureaucrat $G$ concerning the terms of the contract. The total surplus to be divided is given from (2.9) by $S_{M}$. Under the assumption of Nash bargaining, $M$ recelves ${ }_{2} S_{M}$ through the price $P_{0}$. Now move back to date $-k$. At this date, as long as there are many potential (Identical) firns and managers who can run the prison, the politiclan can offer to sell $\mathrm{F}$ to whomever pays the highest bribe: the highest bribe is of course ${ }^{2} S_{m}$ and so this 1 s the politician's payoff.

Now consider the case where the politician keeps F public. How much would $M$ pay for the privilege of being the warden? The problem $M$ faces is that prior to a contract with $G$ being written he has no job security, i.e., if the prison is public there is nothing to stop the bureaucrat from replacing $M$ with another manager at date 0 (no relationship-specific investments have yet been made). Hence M's future payoff is zero, which means that this is also the politician's bribe! The conclusion is that the corrupt politician always wants to privatize F even if this is socially inefficlent.

Even if the politician can force the bureaucrat to retain the manager whom the polftician has selected, the bribes that a politician can extract from this manager are lower than those from a private contractor. If $\lambda<1$, a public sector warden gets less than $1 / 2$ of the benefits resulting from cost reductions or quality improvements that he makes, in contrast to a private contractor, who gets half the gains from quality improvements, and all the gains from cost 
reductions. As a consequence, the ex ante bribe that a public sector manager would pay for his Job is lower than the bribe that a private contractor would pay. To the extent that a politiclan maximizes his bribe, he privatizes excessively.

\section{Patronage}

An equally important consideration ignored by assuming that politicians act In the public Interest is that politiclans often cater to special interest groups, such as labor untons, to win elections (Stigler 1971, Becker 1983). Politiclans may choose to use public money to provide jobs for the workers who then favor them in the elections, or to pay such workers wages above market levels. If spending public resources to transfer wealth to such interest groups is easier with in-house provision than with contracting, then politicians would have a bias toward too little privatization (Shleifer and Vishny 1994). Patronage thus has the opposite effect to that of corruption: it leads to excessive bias toward in-house provision. Interestingly, excessive employment in public firms may lead to excessively high quality (if having more people increases quality). For example, the quality of service in some European state airlines, such as AIr France and Lufthansa, may be excessively high, and a possibly lower quality at private airlines is no evidence of lower efficiency. Avolding excessive public spending on politically powerful interest groups is Indeed one of the principal goals of privatization throughout the world. In the United States, public sector unions are a powerful special Interest group that has delivered some of the most vocal opposition to government contracting, including privatization of prisons (AFSCME, 1985). Some evidence suggests that the presence of strong public sector unions, as well as soft budget constraints 
of the government, are important obstacles to privatization of local government services in the United States (Lopez de Silanes, Shleifer and Vishny 1996).

Positive considerations thus suggest an important tradeoff between privatization and inhouse provision. To the extent that corruption is a serious problen, the case for privatization is weaker than it is under benevolent government. But to the extent that political patronage is a severe problem, the case for privatization is stronger. A reformer considering privatization must have a clear Idea as to whether corruption or patronage is a bigger problem in his polity.

\section{Privatization of Prisons.}

Overview

Privatization of prisons refers to the contracting out by the government of the operations of prisons to private companies. In the middle ages, prisons were typically private, but by the 20 th century, governments in most countries had taken over their operation. In the U.S. today, while private companies by law are restricted from meting out punishment, and public employees are usually present even in private prisons to make decisions on 1ssues that can be interpreted as changes in the severity of prisoners' punishment, almost all the other activities related to incarceration can in principle be privatized. Private prisons have grown rapidly in the United States in the last decade from a capacity of about 1200 prisoners In 1985 to almost 50,000 prisoners at the end of 1994 (Thomas 1995). Still, private prisons house only about 3 percent of the total prison population. Despite their quantitative insignificance, private prisons have stimulated an extenslve debate addressing the cost and quality aspects of private Incarceration (e.g., AFSCME 1985, Donahue 1988, 1989, Logan 
1990, 1992, Shichor 1995 and others). Although there are no large sample studies of elther cost or quality comparisons of public and private prisons, the avallable literature is informative enough for us to assess the relevance of the Incomplete contracting approach to the study of prison privatization.

Private prisons are perhaps 10 percent cheaper, per prisoner, than public prisons $^{14}$. The major reason for the lower costs appears to be the roughly 15 percent wage prenium for public guards over private guards (Donahue 1988). Part of labor cost difference is that private contractors do not pay the public union wage premium, another part is that they hire lower quality workers. Since labor accounts for two thirds of the incarceration costs, the differences in labor costs can roughly account for the 10 percent cost saving from private prisons.

The most controversial and interesting issues raised by private prisons concern the quality of service. Quality covers order in the prisons (security of prisoners, escapes, staff conduct toward prisoners, violence by guards and between prisoners, disclplinary procedures etc), amenities that prisoners receive (quality of food, health care, dental care, mental care, clothes, quality of facilities, prison work, entertainment, access to legal help, etc), and rehabilitation (vocational training, other education, parole procedures, etc). Objections to prison privatization typically focus on quality. To quote Dilulio (1987), "The history of private sector involvement in corrections is unrelievedly bleak, a well-docunented tale of inmate abuse and political corruption. In many Instances, private contractors worked inmates to death, beat or killed them for

\footnotetext{
${ }^{16}$ The comparisons are of ten disputed by critics of prison privatization, since private prisons apparently get somewhat less violent prisoners (Donahue 1988, Shichor 1995), and since some of the costs of private incarceration -. such as the continued need for public oversight - - are often ignored in the comparison. On the other hand, some of the costs of public prisons, such as foregone tax revenues and often even capital costs, are also often ignored in the comparisons.
} 
anor rule infractions, or falled to provide inmates with the quantity and quality of life's necessities (food, clothing, shelter, etc.) specified in their often meticulously-drafted contracts." This account is not extreme among those by critics of private prisons, such as Webb and Webb (1963) and Shichor (1995, Chapter 2). On the other hand, Logan (1992) reports the results of a survey of three women's prisons in New Mexico that point to superior quality of the private prison. The central question of prison privatization is whether the poor history Is a good gulde to the present and the future.

Our theoretical analysis helps organize some of the thinking about prison privatization around the questions of what contracts can and do accomplish. Accordingly, we show first that many of the quality problems in incarceration can actually be addressed through contracts. Nonetheless, we also show that serious and unavoldable incompleteness remains even in the "best practice" existing contracts. Moreover, the incompleteness takes the form described in the model: contractors have an opportunity to reduce costs in ways that may lead to a substantial deterloration of quality. We also address the highly pertinent problems of corruption and poor enforcement of contracts. We conclude the section with some tentative recommendations concerning the privatization of prisons.

What contracts can accomplish

To assess the possibllities of contracting, we examine modern "best practice" In the United States, which surely overestimates the average practice. First, some private prison contracts have obligated the contractor to adhere to the standards of the American Correctional Association, a pseudo-public body that issues standards for good prisons (e.g., ACA 1990) and accredits prisons 
that neet them. Second, the American Bar Association has made a tougher set of proposals for what a good contract should look like (Robbins 1989). Finally, we briefly examine a real contract between Davidson county in Tennessee and the Corrections Corporation of American (CCA). The State of Tennessee has taken privatization of prisons more serlously than any other state, and CCA is one of the most reputable contractors in the private prisons business. By examining these documents, we hope to look Into what contracts if enforced can accomplish.

The American Correctional Assoclation proposes 463 standards for adult correctional Institutions dealing with virtually all aspects of prison life. The standards cover administration and management of prisons (including personnel policies, staff training and development, bookkeeping, fiscal management, etc.), physical plant (including bullding and safety codes, security, inmate housing, prison size, etc.), operations (Including rules and discipline, security procedures, inmate rights, special confinement, etc.), services (including inmate classification, food, hygiene, health care, social services, etc.), and inmate programs (work, education, recreation, mall, visiting, library, religion, etc.). of these standards, thirty eight are mandatory and cover such key 1ssues as training and staff development, bullding and safety codes, security and control, safety and emergency procedures, Inmate rights, classification, food service, sanitation and hyglene, health care, and work in correctional industries. To get ACA accreditation, which is renewed every three years, an institution must meet all thirty eight mandatory standards and ninety percent of the nonmandatory standards. In general, only a small percentage of elther public or private prisons get ACA accreditation. However, even if a private prison does not get ACA accreditation, a prison contract can use some or many ACA standards as contract provisions. 
ACA standards tend to be process rather than outcome oriented. Specifically, ACA standards typically insist that a facllity have a written set of rules or a policy manual dealing with various matters, as well as staff to attend to these matters. ACA standards usually do not specify the content of these rules. Presunably, the 1dea of having a manual is to help train prison staff, as well as to enable inmates to complain (or sue) if the written rules are violated - something they could not do without a manual to point to. On some matters, however, such as food and health, ACA does specify minimum quality standards that would be relatively difficult to get around. On food, ACA specifles the number of meals that must be served, caloric intake, time between meals, conditions for preparation and keeping of food, as well as palatability. It also refers to the standards of the American Dletetic Association on food quality. If a government writes a contract obligating a private contractor to receive ACA accreditation, it can address many of the standard quality concerns.

Robbins (1989), In a document endorsed by the American Bar Association, proposes a tougher approach to contracting than that of the ACA. Robbins' approach is to adhere to ACA standards in substance, but then to introduce draconian liabilities for contractors who elther violate the contract or prisoners' civil rights. For example, Robbins wants private contractors to meet 100 rather than 90 percent of ACA non-mandatory standards. He also wants contractors to carry $\$ 25$ million of liability insurance per occurrence of violation of Inmate rights, which would perhaps protect the government from 1lability, but would almost surely put private prisons out of business. ${ }^{15}$

15 Robbins also wants to mandate that private contractors hire the former employees of facilitles previously run by the government at or above their previous wages. This would eliminate the cost advantage of the private contractors. 
Robbins' proposal 1s sintlar to contracting for the highest quality in all states of the world, which in general is not efficient ${ }^{16}$.

A look at a 1990 contract between the Corrections Corporation of America (CCA) on the one hand, and the Metropolitan Government of Nashville and Davidson County, Tennessee on the other, suggests that ACA standards can play a pivotal role in contracting. This contract covers the construction and three years of operation of a prison by CCA, to be compensated by a fixed construction fee plus a per dien rate for prisoners. The contract clearly specifies that CCA must achieve accreditation of the prison by the ACA within two years of the service commencement day, and more generally relies very heavlly on ACA standards, particularly in the matters of amenities and service. The contract also specifles that three government employees must be permanently present at the premises, Including the Contract Monitor, in order to monitor contract performance as well as review disciplinary and appeals reports ${ }^{17}$.

Overall, the Impression conveyed by the ACA standards, Robbins' proposals, and the actual contract is that .. If best practice is followed - - many aspects of the quality of incarceration can be addressed through contracting.

${ }^{16}$ The key assumptions of the model of Section 2 - that quality cannot be contracted on - really stands for something more subtle, namely the idea that it is too costly to specify the efficient quality level corresponding to every possible state of the world. It is not a contradiction of the model if some quality level can be specifled in all circumstances; the point is that this quality level may be too high or too low. Robbins' (1989) proposal illustrates this point. His approach can be thought of as an attempt to make quality contractible. The problem is that it does so by choosing quality so high that it is arguably uneconomic to supply $1 t, e . g .$, the prison may be forced to take so many precautions to avold escapes that it cannot make a profit. In other words, it would be as if someone who wanted a secure house bullt were to "solve" the contracting problem by specifylng that the house should be impregnable against all disasters, including nuclear attack. Not surprisingly, no public prison satisfles Robbins' criteria.

17 Robbins wants public employees to play a more active role in discipline and appeals than the Tennessee contract envisions. 


\section{Contractual Incompleteness}

Although contracts can address some quality 1ssues, in several important areas incompleteness is evident, and can in principle compromise the quality of service delivered by a private contractor. The two cruclal areas we concentrate on are use of force and quality of personnel. These areas have been the focus of much of the criticisms of private prisons. In both of these areas, "best practice" contracts appear to be serlously incomplete in ways that can easily lead to quality deterioration.

A famous court case, Medina v. O'Neill (1984), fllustrates the persistent concerns about both the excessive use of force and the poor quality of personnel In private prisons. According to Shichor (1995), "In 1981, in Houston, 26 stowaways were detained by the Immigration and Naturalization Service. At first, 20 of the detainees were held at the local jall and 6 of them were placed with a local private security flrm. The private firm placed them in a cell designed to hold six people. A day later 10 of the 20 detainees held in the jall also were transferred to the private flrm for custody, and they were placed in the same ce11, which was already filled to its capacity (Logan, 1990). In this situation 16 illegal Immigrants were held in a $12 \mathrm{ft}$ by $20 \mathrm{ft}$ holding cell. A day after the transfer of the 10 allens to the private facility, the detainees tried to escape from the facility and a private guard in his attempt to prevent the escape accidentally killed one of them with a shotgun and serfously wounded another one. The private guard apparently was untrained in the use of firearms, and his intention was to use his gun as a cattle prod to force the detainees back to their cell (p. 104)." Interestingly, when ruling on this case, the Fifth Circuit Court of Appeals overturned a lower court ruling against the INS and held that "(1) INS officials had no statutory duty to provide appropriate detention 
facilities for excludable allens, and (2) allens' due process rights were not violated" (Logan 1990, p. 183). In short, guards can use excessive force, guards may be untrained, and still courts see no violation of law (or contract). AFSCME (1985) and Donahue (1988) offer additional examples of the poor training and low hunan capital of private prison personnel.

An examination of other sources on contracts points to significant Incompleteness. The mandatory ACA standard on the use of force is not espectally detalled: - Uritten policy, procedure, and practice restrict the use of physical force to instances of justifiable self-defense, protection of others, protection of property, and prevention of escapes, and then only as a last resort and in accordance with appropriate statutory authority. In no event is physical force Justifiable as punishment. A written report is prepared following all uses of force and is submitted to administrative staff for review." A separate, but equally vague, mandatory standard governs the use of firearms. Even the Robbins suggestion on the use of non-deadly force is brlef: "any failer shall be authorized to use only such non-deadly force as circumstances require in the following situations: to prevent the commission of a felony or misdemeanor, Including escape; to defend oneself or others against physical assault; to prevent serfous damage to property; to enforce institutional regulations and orders; and to prevent or quell a rlot." 18 Robbins is tougher on contractors In some respects (damage to property has to be serious), although he opens a very wide door for the use of force by allowing the contractor to enforce Institutional regulations and orders", which covers just about anything. These

${ }^{18}$ Spectfying the circumstances when the use of deadly force is allowed is typically easier, since such force is normally used only in the event of escapes and riots, both of which are veriflable. See Shichor (1995, p. 101) for a discussion. 
standards suggest to us that, whether the contractor is ACA accredited or even restrained by the ABA, his discretion in the use of non-deadly force is enormous.

The Tennessee contract allows even wider latitude in the use of force. First, In contrast to elther the ABA or ACA, use of deadly force is allowed to prevent escapes. Second, in the use of non-deadly force, the Tennessee contract follows Robbins recommendations (without specifylng his penalties), which probably does not restrict the use of force in significant ways. In sum, even the best practice contract allows wide latitude in the use of force.

Perhaps even greater contractual incompleteness prevails in the area of the quality of personnel. The ACA (non-mandatory) standards require that a procedure be used to determine staffing needs, and that the vacancy rate be kept under 10 percent for any 18 month perlod. Correctional officers are also required to receive 120 hours of training in their first year, and 40 hours in subsequent years. Little is sald about the quality of the training (except for topics covered) or the quality of the officers. Robbins generally follows ACA standards. The Tennessee contract follows the ACA on training, but also specifies that at the time the facility opens and during the first year of the contract, a minimum of 25 percent of contractor's security employees will have at least one year of corrections security experience. Davidson County residents will be given a hiring preference in staffing the facility". What is most Interesting about these standards is how few there are, and how much discretion the contractor has in saving costs on personnel.

Does contractual incompleteness lead to the deterioration of quality? Unfortunately, no systematic evidence is avallable on this matter. We can get a glimpse of the issues by looking at two (very small sample) reports. The first is a comparative evaluation of two public prisons and one private (CCA-managed) 
prison in Tennessee, done by that state's government (State of Tennessee 1995). Although this evaluation has concluded that all three prisons are overall of extremely high quality, with the implication that a cheaper private prison is a good deal for the state (see also the NYT, 9/19/1995), It is clear from the body of the report that the level of violence is higher in the private prison: "The number of injuries to staff and prisoners is a measure of the security and safety of the facility. During the fifteen month period, the private prison reported significantly more (214) Injurles to prisoners and staff, compared to 21 and 51 for the two state prisons, respectively. The private prison also reported 30 Incidents of the use of force, compared to 4 and 6 , respectively, for the state prisons". The Tennessee report minimizes this evidence because of the possible differences in reporting practices, but it is suggestive nonetheless.

All three Tennessee prisons had ACA accreditation. However, they did not meet 100 percent of non-mandatory ACA standards, and the areas in which the prisons falled to meet the standards were different for the private and public prisons. One of the public prisons seems to have been most lacking in meeting food service standards: It met only 44 percent of them on the first inspection and 67 on the second. The second state prison met only 64 percent of fire and occupational safety standards on the first inspection, although it was up to 97 percent in the second Inspection. The private prison on the first inspection had the largest problem with personnel standards, of which it met only 73 percent, and with food service, where it met 67 percent of standards. It also had problems with health care, health records, and mental health service standards, where it had about 75 percent compliance. By the time of the second inspection, the private prison was up to 92 percent compliance on personnel standards (still below state prisons), and had straightened out most of its other failures. It 
is difficult to gauge from the report whether the reason that the three prisons look exemplary on the second inspection is that they were expecting the evaluation. However, the inferior performance of the private prison on personnel natters is consistent with the view that the area of personnel is where the noncontractible savings 1 le in private prison managenent. The higher incidence of violence in the private prison might well be a consequence of inferior staff, since undertrained guards may be more likely to use force to prevent violence between Inmates.

CCA private prisons in Tennessee are widely regarded as a success of private prison management. ESMOR's detention facility in Elizabeth, New Jersey, operated for the Immigration and Naturalization Service (INS), is widely regarded as a fallure, In part because a riot broke out at that facility on June 18, 1995. The highly critical INS report on this facility, as well as newspaper accounts, provide some additional information about a private prison - - although we should stress that this piece of evidence might represent the worst case. The facility housed foreign nationals who were caught attempting to enter the US illegally through Kennedy and Newark alrports, and who were awaiting deportation -. not exactly a hard core criminal crowd. ESMOR won the INS contract by significantly underbidding another private competitor, in part because it assumed in its bid lower wage rates for prison staff. The contract actually specified the types of workers that ESMOR was supposed to hire, but it turned out to be possible within the contract to hire as guards individuals who previously guarded goods in warehouses. With training, ESMOR evidently just violated the contract: the INS reports that ESMOR ' did not meet requirements of the contract' in this area.

Overall, the ESMOR facility was seriously understaffed, guards did not recelve enough training, guards were implicated in incidents of physical abuse 
of prisoners, and supervision of staff by management was lacking. When the riot broke out, the guards Immediately ran away, and called the polfce from a payphone. INS attributed many of the problems at the facility to ESMOR's cutting corners, princtpally on labor. The evidence in the report points to the possibllity of cost savings by private contractors at the expense of quality, although this particular eplsode raises the equally important issue of government's fallure to respond to explicit contract violations by the contractor.

In sum, while systematic evidence on the quality of Incarceration by private and public prisons is not avallable, the existing shreds of evidence suggest that in important dimensions, such as prison violence and the quality of personnel, prison contracts are seriously incomplete. This incompleteness can, and evidently sometimes does, give rise to quality shortfalls in private contracting.

\section{Contract Supervision and Oversight}

Our discussion so far has stuck to the model of a benevolent government writing and enforcing a contract, limited only by the difficulties of writing good contracts. The history of private incarceration, however (11ke much of the rest of history of government), points to the common incidence of corruption in allocating contracts, as well as to deficient contract enforcement. Shichor (1995), for example, tells a disquieting tale of corruption and prisoner maltreatment in private prisons in California in the 19th century. The first private prison contract went to James Estell, a politically powerful member of the legislature, who used his authority to enrich himself and his friends with lucrative subcontracts while abusing prisoners (Shichor, 1995, p. 40). How does 
the present practice compare with the past?

The exanination of ESMOR and other evidence indicates that the Issues analyzed In Section 5 remain germane to actual prison contracting. First, private prison companies are very active politically. For Instance, ESMOR evidently lobbies politiclans and makes political contributions to receive contracts (New York Tines, $7 / 23 / 1995)$. The wife of Tennessee governor Lamar Alexander Invested early and profitably in the stock of Corrections Corporation of America, which subsequently got Involved very deeply in the privatization of Tennessee prisons with the governor's endorsement (The New Republic, 3/4/96, p. 9).

Second, contract enforcement cannot be taken for granted. The INS report concludes that ESMOR' $s$ changes in policies 'hindered INS ability to effectively perform its oversight functions". The report also notes that ESMOR told its guards not to share information with the INS officlals working on the premises, and in one instance encouraged the INS to reassign an officer who complained about the performance of the Elisabeth, N.J. facllity several months prior to the riot. The report Indicates that ESMOR violated the contract in some instances, and also pursued policles preventing INS from enforcing the contract. But it is also clear from the report that INS did not do what it could to enforce this contract. The INS report vividly illustrates how a government bureaucracy with relatively weak incentives has trouble enforcing a contract with a private supplier determined to reduce its costs, even if this involves violations of the contract and not just the issues on which the contract is silent.

Third, the INS contract Imposed no or light penalties for performance failures (e.g., as far as we can tell, $\$ 80$ as a penalty for an escape, of which there were dozens from the start), and was generally extremely soft compared, for example, to the Tennessee contracts. ESMOR is even negotiating with the INS 
about the resumption of operations in the Elizabeth, N.J., facility. The costs of contract violations to the private contractor, therefore, do not appear to be very high.

In the case of prisons, then, the benevolent government perspective might give an excessively optinistic picture of private contracting.

\section{Should prisons be privatized?}

Prisons seem to fit reasonably well into our framework. Although in some respects prison contracts are very detalled, they are still seriously incomplete. There are significant opportunities for cost reduction that do not violate the contracts. These cost reductions, at least in principle, can lead to a substantial deterforation of quality. Moreover, from the available evidence we have the impression that the world may not be far from the assumptions of proposition 4. First, the welfare consequences of quality deterioration might be of the same magnitude as those of cost reduction. Second, the opportunities for quality innovation are limited. Under these conditions, proposition 4 suggests that public ownership is superior. That is, private contractors may seriously reduce quality in the process of reducing costs, and, moreover, the benefits from the potential quality Innovation by the private contractors are 1imlted. We also note that, without prisoner cholce, ex post competition, which addresses the quality problems that may result from privatization of other activities, does not play a large role in incarceration. Finally, corruption seems to be a more severe problem in this business than patronage, since the union premlum as of this writing is not large. For all these reasons, our theory suggests significant skepticism about private incarceration.

One instance in which the case against prison privatization is even 
stronger is maxinum security prisons, where the prevention of violence by prisoners against guards and other prisoners is one of the most important goals of Incarceration (New York TImes Magazine, November 26, 1995). In many cases, the principal atrategy for preventing such violence is the use of force by the guards. We have shown that it is very difficult to delineate contractually the permissible circumstances for the use of such force. Moreover, hiring less educated guards and undertraining them .. which private prisons have a strong Incentlve to do - can encourage the unwarranted use of force by the guards. As a result, our arguments suggest that maximum security prisons should not be privatized as long as limiting the use of force against prisoners is an important public objective. Consistent with this view, only 4 of the 88 private prisons in Thomas's (1995) census of private adult correctional institutions in the U.S. are maximum security. In contrast, private halfway houses and youth correctional factlities, where violence problems are much less serfous, are extremely common (Shichor 1995).

6. Other activities.

In some ways, the model we presented was constructed to fit prisons. However, our model helps us to analyze other activities as well, as we show in this section. In the process, we also examine some of the model's limitations.

\section{Garbage Collection}

Garbage collection illustrates a case where our model clearly points to the benefits of privatization. In this case, the damage to quality resulting from the private contractor hiring inferior employees or failing to maintain the equipment is probably trivial $(b(e)$ is low). Our analysis then implies that 
private provision is superior. This result obtains even though in garbage collection ex post competition is extremely expensive, since it is essential that the same company plck up garbage from nelghboring houses (Donahue 1989). The superiority of private provision in garbage collection is documented by several empirical studies (Donahue 1989).

\section{Weapons Procurement}

Weapons procurement is another case where our model points to the superfority of private provision. Although the damage to quality from cost reduction might be significant, to a large extent this damage could be contracted around, since weapons must meet well-speciffed performance requirements. Moreover, quality innovation is enormously important in weapons design, and the incentives of private suppliers are probably significantly stronger than those of public employees. As a consequence, if $b(e)$ can be limited through contracts, Proposition 3 points to the superiority of private ownership.

Foreign Policy

In many situations, the nature of the service that the government wants to be performed is extremely complex and unpredictable, so any contract is inherently extremely incomplete. Most actual decisions of the contractor have to be renegotiated at the government's initiative, which exposes the government to the high costs of paying up to the contractor who has a lot of power. For example, as Wilson (1989) shows, it is virtually impossible to describe in advance what services need to be performed to carry out American foreign policy, a task now assigned to the State Department. Suppose that the State Department were to be privatized, and a set of policles toward different countries specified 
In the contract. In this case, when the government wants to change its policy toward a country (say because Russia renounces communism), it would have to pursuade the private contractor to change what it does. In this renegotiation, the government presumably would have to pay the private contractor more than it would pay an employee, who is totally replaceable when no ex ante investments are needed. Inhouse provision in this case of few investments and enormous ex post holdup opportunities seens clearly superior.

A skeptic can respond to this analysis by suggesting that perhaps ex ante, the government should auction off the foreign policy contract for a vast amount of money with an understanding that it is going to be regularly held up ex post. What is wrong with this arrangement? In our theory, we have assumed that $M$ is wealthy enough to pay up front for the right to own $F$ when private ownership is optimal. However, in some cases, such as the conduct of foreign policy, M may not be wealthy enough. This creates a further argument for public ownership when M's ex post holdup power vastly exceeds the amount he can raise ex ante for the contract. If $M$ cannot compensate $G$ In advance for all the future holdups when $G$ changes the contract, then the extraction of surplus from $G$ by $M$ is socially wasteful. Hence the government may wish to own F simply to avoid having to compensate $M$ when $1 t$ changes 1 ts mind at date $1^{19}$. This logic thus confirms the conclusion that forelgn policy should be conducted by government bureaucrats.

${ }^{19}$ This argument is developed further in Trinh (1996). One may ask why $M$ couldn't borrow against the recelpts from his future hold-up opportunities. The answer is that a bank may be unwilling to lend to $M$, since there is nothing to stop M from "holding up" the bank by refusing to hold up the government. That is, having received his loan, M can threaten not to hold up the government at date 1 and use this threat to renegotiate downwards his repayment to the bank (Hart and Moore 1994). Anticipating this, the bank will refuse to lend to $M$. 


\section{Schools}

An 1mportant example that goes outside of our basic model is the provision of schooling. For schools, the damage to quality from cost cutting, $b(e)$, may be large, but innovation is probably important and the incentives of publicly employed teachers, espectally when they are protected by unions, are weak. Our propositions, therefore, do not give a clear answer as to which arrangement is superior. The key aspect of schools, however, is the potential for ex post competition. In voucher arrangements combined with school choice, for example, the government pays for each child's education, but chlldren and parents can select schools. While we have not analyzed our model in this case in detail, our conjecture is that the case for such private arrangements is extremely strong. School cholce would force private schools to compete for students by providing higher quality, since schools cannot compete in prices when students pay with vouchers. This competition should significantly reduce the incentive to cut quality while cutting costs, as well as increase the incentive to innovate quality. Indeed, the available evidence seems to suggest that competition between schools is associated with a higher quality of education (Hoxby 1994). Critics of vouchers and school choice often point to a particular aspect of quality that they believe would fall as a result of privatization, namely reduction of access of some students to good education. Specifically, critics fear that sorting of students by ability would increase as a result of such arrangements, which they regard as socially undesirable. Such sorting can take two forms. First, good private schools pald with vouchers would select the best students, leaving the not-as-good students to not-as-good schools. Second, private schools would avold expensive to educate children altogether, who would then get stuck in residual government programs. Critics charge that such 
outcones are less socially desirable than those involving less sorting. Some school districts have trled to solve these sorting problems contractually by, for example, using courts to allocate students to private schools that wish to be paid with vouchers (Moe, ed. 1995). Whether contracts can successfully address the concerns of the critics of school choice, and whether these concerns are actually justifled from the social welfare vlewpolnt, are question requiring further inquiry.

\section{Healthcare}

In the case of healthcare, as with education, the government wants to pay for the services of at least some consumers, and needs to design a good arrangement for doing so. One aspect of this design concerns whether hospitals should be private or public. In the analysis of optimal ownership, there are sone similarities between schools and hospitals, as well as some differences. To begin, in healthcare, as In education, gains from Innovation are enormous, but so is the damage to quality from cost-cutting. Moreover, the distributional aspect of quality is extremely important in both services: the danger that expensive-to-treat consumers would be denied care if the government pays less than it costs to treat them is always present.

One further simllarity is that ex post competition between hosptials .. letting patients choose their hospital -. can play a role in healthcare, and we argued above such competition may strengthen the case for privatization. However, a cruclal difference is the limited ability of consumers to assess the quality of healthcare they recelve. Consumers generally cannot tell whether hospltals have falled to provide care to save costs, and hence would not as readily change suppliers in response to poor quality. For this reason, the 
combination of private ownership and competition would not be nearly as effective In healthcare as in education, making the case for some government ownership stronger.

Perhaps because of all these concerns about private provision, most countries have responded to the need to provide healthcare to all their people through government provision. The United States has been different in relying on both private and public hospitals, with the latter taking care primarily of indigent patlents. Historically, private hospitals have been paid on the cost plus basis - an approach that our model does not accommodate (since we assume that costs are nonverifiable) but which, unsurprisingly, has proved extremely expensive. More recently, the form of compensating providers has shifted to fixed fees for services, a contract very similar to that analyzed in our model. Not surprisingly, these contracts have increased concerns about quality deterforation, particularly in the so-called Health Maintenance Organizations. An analysis of healthcare would require a significant generalization of our model, especially since verification of costs and cost-plus contracts have played an essential role in paying for this service. This is a very important topic for future research.

\section{Police and Armed Forces}

As our last example, we consider some basic services provided by the government that nobody seriously thinks of privatizing: the police and the armed forces. Our framework helps to explain why these services should not be privatized.

If the police or armed forces were privatized, the owners of the resulting private companies would have enormous power. Part of this power would stem from 
the direct ownership of weapons that are currently in public hands. The owners could use this power to hold up the government and society. For example, suppose as an extrene case that nuclear weapons were sold off to a private company and an (Incomplete) contract was written with the company as to how these weapons should be used in the event that the country is threatened with attack. The concern Is obviously that the private company would wriggle out of the incomplete contract and either threaten to withhold the weapons in the event of an emergency to extract a huge side-payment from the government, or even threaten to use the weapons against the country itself unless it recelves such a side-payment.

We stress that keeping the nuclear stockpiles - or armed forces - - public does not eliminate the possibility of attempted holdup. A general who is a state employee could use his access to nuclear weapons to attempt to hold up society. After all, coups and rebellions by the armed forces do sometimes occur. However, there is a difference between the private and public cases. If nuclear weapons or the armed forces are publicly controlled, the government can take early action to prevent a potential holdup. If it suspects that an errant general is engaged In treasonous activities, it can fire the general. In contrast, in the private case, it would have to wait unt1 a clear breach of contract occurred; this might be too late. In our model, a public general can be kept replaceable almost at all times, whereas a private $M$ can make substantial investments to make himself costly to replace.

\section{Conclusion.}

We have examined the conditions that determine the relative efficiency of Inhouse provision vs outside contracting of government services. Our theoretical arguments suggest that the case for inhouse provision is generally 
stronger when non-contractible cost reductions have large deleterious effects on quality, when quality innovations are unimportant, and when corruption in government procurement is a severe problem. In contrast, the case for privatization is stronger when quality-reducing cost reductions can be controlled through contract or competition, when quality innovations are important, and when patronage and powerful untons are a severe problen inside the government.

We then applied this analysis to several government activities using the avallable evidence on the Importance of various factors. We concluded that the case for inhouse provision is very strong in such services as the conduct of foreign policy and maintenance of police and armed forces, but also can be made reasonably persuasively for prisons. In contrast, the case for privatization is strong in such activitles as garbage collection and weapons production, but also can be made reasonably persuasively for schools. In some other services, such as provision of healthcare, an analysis of efficlency of alternative arrangements Is a great deal more complicated and requires a much more detailed model of competition and regulation than we could provide in this paper. We defer such analysis to future work. 
Bibllography.

American Correctional Association (ACA), Standards for Adult Correctional Inst1tutions. 3d Edition (Laurel, MD: ACA, 1990).

Anerican Federation of State, County and Municipal Employees (AFSCME), Dees Crime Pay? An Examination of Prigons for Profit (Washington. DC: AFSCME, 1985).

Becker, Gary S., "A Theory of Competition Among Pressure Groups for Political Influence," Quarterly Journal of Economles, 98 (1983), 371-400.

DiIul10, John J., Jr., "Private Prisons," unpublished discussion paper, May 1987. Domberger, Simon, Christine Hall, and Eric L1, The Determinants of Price and Quality In Competitively Tendered Conctracts, Economic Journal, 105 (1995), $1454-1470$.

Donahue, John, Prisons for Profit: Public Justice. Private Interests (Washington, DC: Economic Policy Institute, 1988).

, The Privatization Decision: Public Ends. Private Means (New York: Basic Books, 1989).

Grossman, Sanford J., and Ollver D. Hart, "The Costs and Benefits of Ownership:

A Theory of Vertical and Lateral Integration," Journal of Political Economy, 94 (1986), 691-719.

Hart, Oliver, Elrms Contracts, and Financlal Structure (Oxford: Oxford University Press, 1995). and John Moore, "Property Rights and the Nature of the Firm," Journal of Polftical Economy, 98 (1990), $1119-58$. - "A Theory of Debt Based on the Inalienability of Human Capital, " Quarterly Journal of Economics, CIX (1994), 841-80. Holmstrom, Bengt, and Paul Milgrom, Multi-task Principal-Agent Analyses: 
Incentive Contracts, Asset Ownership and Job Design," Journal of Law Economics and Organtzation, 7 (1991), 24-52.

, "The Flrm as an Incentive System," American Economic

Reylew, 84 (1994), 972-91.

Hoxby, Caroline, "Does Conpetition Among Public Schools Benef1t Students and

Taxpayers?" NBER Working Paper \#4979, December 1994.

Klein, B., R. Crawford and A. Alchian, "Vertical Integration, Approprlable Rents, and the Competitive Contracting Process," Journal of Law and Economics, 21 (1978), 297-326.

Laffont, Jean-Jacques, and Jean Tirole, A Theory of Incentives in Regulation and Procurement (Cambridge: MIT Press, 1993).

Logan, Charles H., Private Prisons: Cons and Pros (New York: Oxford University Press, 1990).

- "Well Kept: Comparing Quality of Confinement in Private and

Public Prisons," Journal of Criminal Law and Criminology, 83 (1992), $577-$ 613.

Lopez-de-Silanes, Florencio, Andrel Shleifer and Robert W. Vishny,

"Privatization In the United States," Harvard Discussion Paper \#1723, 1996.

Metropolitan Government of Nashville and Davidson County, "Design, Construction and Management Service Contract between CCA and Metropolitan Government of Nashville and Davidson County," 1990.

Moe, Terry, ed, Private Vouchers (Stanford, CA: Hoover Institution Press, 1995). New York Times, "In Corrections Business, Shrewdness Pays, " July 23, 1995, p. 1. , "Private Tennessee Prison is Pralsed In State Studies," September 19, 1995, p. 7.

, "The Pitfalls of Private Penitentiaries," November 24, 1995, P. A1. 
New York Times Magazine, "The Toughest Job in America is Getting Tougher," Novenber 26, 1995, P. 42 .

Robbins, Ira P., "The Legal Dimensions of Private Incarceration," The American University lay Review, 38 (1989), 531-854.

Savas, Eaanuel, Privatizing the Public Sector: How to Shrink Government (Chathan, NJ: Chathan House Publishing, 1982). - Brivatization: the Key to Better Government (Chatham, NJ: Chatham House Publishing, 1987).

Schmidt, Klaus, "The Costs and Benefits of Privatization: an Incomplete Contracts Approach," Journal of Law Economics and Organization, 12 (1996), $1-24$.

Shapiro, Carl, and Robert Willig. "Economic Rationales for the Scope of Privatization," In Ezra N. Suleiman and John Waterbury, eds., The Political Economy of Private Sector Reform and Privatization (Boulder, CO: Westview Press, 1990).

Shleifer, Andrei, and Robert W. Vishny, "Corruption," Quarterly Journal of Economics, CVIII (1993), 599-618. . "Politicians and Firms," Quarterly Journal of Economics,

CIX (1994), 995-1025.

Shichor, David, Punlshment for Profit (Thousand Oaks: Sage Publications, 1995). State of Tennessee, "Comparative Evaluation of Privately-managed CCA Prison and State-managed Prototypical Prisons," February 1, 1995

Stigler, George, "The Economic Theory of Regulation," Bell Journal of Economics, $2(1971), 3-21$.

Thomas, Charles W., Private Adult Correctional Facillty Census (Gainsville: Center for Studies in Criminology and Law, 1995). 
Tirole, Jean, "The Internal Organization of Government," Oxford Economic Papers, 46 (1994), 1-29.

Trinh, Cong Minh, "Three Essays on the Economics of Governance," Ph.D.

Dissertation, Harvard University, 1996.

United States Imigration and Naturalization Service, The Elizabeth, N.J. Contract Detention Fac1lity Operated by ESMOR, Inc.: Interim Report, July 20, 1995.

Vickers, John, and George Yarrow, Privatization: An Economic Analysis

(Cambridge, MA: MIT Press, 1988).

Webb, Sidney, and Beatrice Webb, English Prisons Under Local Government (Camden, CT: Archon Books, 1963, reprint of 1922 Edition).

Williamson, 0., The Economic Institutions of Capitalism (New York: Free Press, 1985).

Wilson, James Q., Bureaucracy: What Government Agencies Do and Why They Do It (New York: Baslc Books, 1989). 


\begin{tabular}{|c|c|c|}
\hline $\begin{array}{l}\text { H and G } \\
\text { write contract } \\
\text { and choose } \\
\text { ownership }\end{array}$ & $\begin{array}{l}\text { M } \\
\text { chooses } \\
i \text { and e. }\end{array}$ & $\begin{array}{l}\text { If no renegotiation, } \\
\text { basic good supplied. } \\
\text { However, renegotiation } \\
\text { will occur. }\end{array}$ \\
\hline
\end{tabular}

Figure 1 

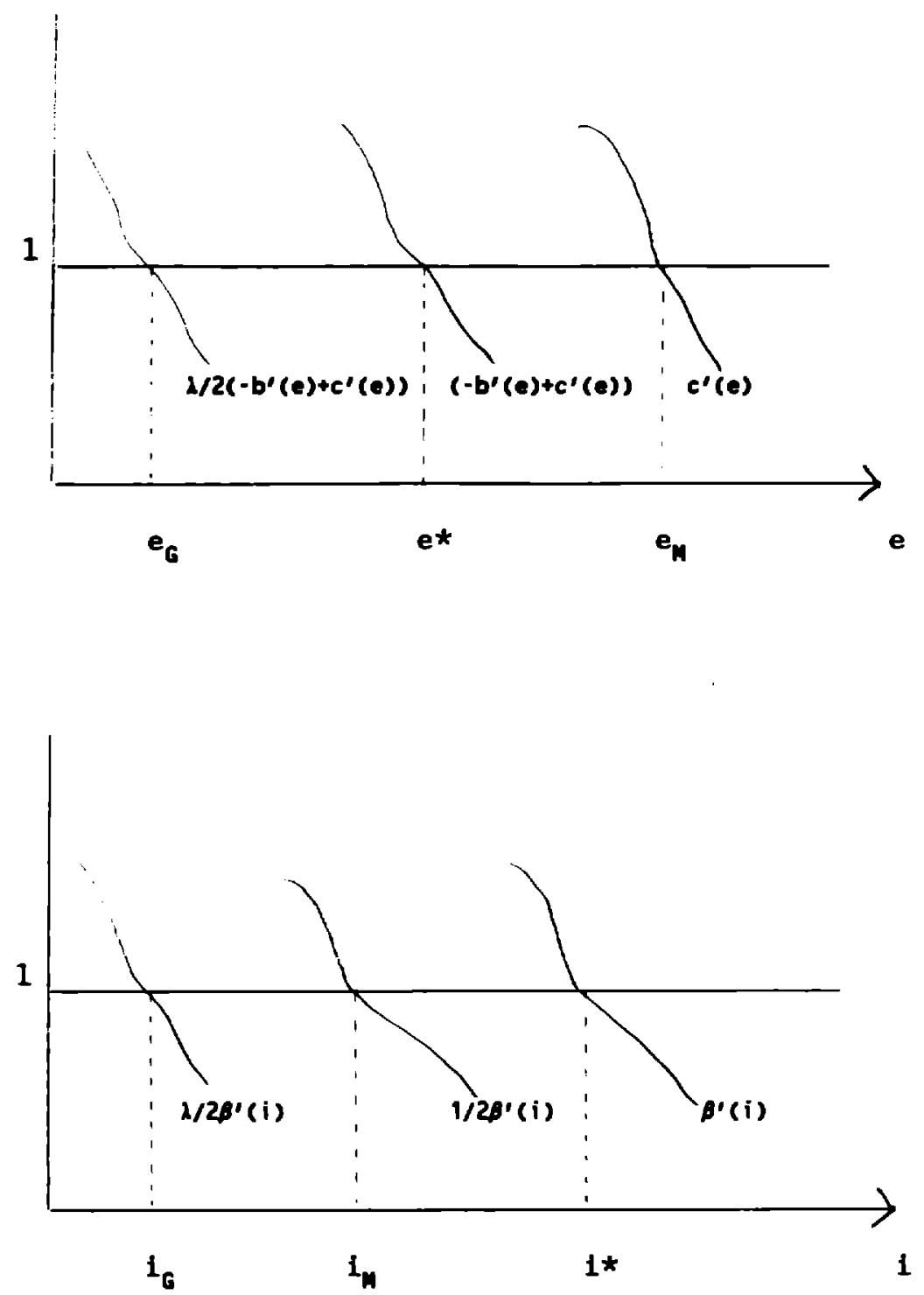

Figure 2 